\title{
Agronomic Performance of Cultivars of Upland Rice in the Southern of the Region of Rondônia, Brazil
}

\author{
Edimar Rodrigues Soares ${ }^{*}$, Robertt Fernandes ${ }^{2}$, Laercio da Silva Londero ${ }^{3}$, \\ Diego Lopes dos Santos ${ }^{3}$, Samara Cristina Sampaio Corrêa ${ }^{3}$, \\ Everton Augusto Sampaio Corrêa ${ }^{3}$, Remy Carvalho dos Santos ${ }^{3}$, \\ Ariel Pereira Gomes, ${ }^{4}$ Leandro Galon ${ }^{5}$, Fabiana Ferreira Pires ${ }^{4}$, \\ Rosilene da Silva Gonçalves ${ }^{3}$ \\ ${ }^{1}$ Department of Soil Science, São Paulo State University (UNESP), Jaboticabal, Brazil \\ ${ }^{2}$ Department of Agronomy, Federal Institute of Education Science and Technology of Rondônia (IFRO), \\ Colorado do Oeste, Brazil \\ ${ }^{3}$ Department of Agronomy, College Amazon (FAMA), Vilhena, Brazil \\ ${ }^{4}$ Agronomist, Federal University Mato Grosso (UFMT), Cuiabá, Brazil \\ ${ }^{5}$ Department Herbology, Federal University of the Southern Border South (UFFS), Erechim, Brazil \\ Email: ${ }^{*}$ soares-agro@hotmail.com
}

Received 18 February 2014; revised 26 April 2014; accepted 13 May 2014

Copyright (C) 2014 by authors and Scientific Research Publishing Inc.

This work is licensed under the Creative Commons Attribution International License (CC BY). http://creativecommons.org/licenses/by/4.0/

(c) (7) Open Access

\begin{abstract}
The upland rice is grown in most Brazilian states. However, in many of them the yield obtained is low. The choice of cultivar more suited to a particular environment can contribute to increased productivity of this crop. This research aimed to evaluate the performance of a hybrid cultivar of upland rice (Ecco) and five conventional cultivars (BRS Monarca, BRS Primavera, AN Cambará, BRS Sertaneja and BRS MG Curinga) in two environments (Vilhena and Cerejeiras). The tests were conducted in the agricultural year 2010/2011. We evaluated the following characteristics: tillering, panicle number per unit area, number of filled grains per panicle sterile, mass of grains per panicle, 1000 grain weight, grain yield $\left(\mathrm{kg} \cdot \mathrm{ha}^{-1}\right)$ and whole grain yield. There was no cultivar $\mathrm{x}$ environment interaction for all traits. Greater tillering, higher panicle number per area, higher productivity and yield of whole grains in the municipality of Cerejeiras were observed, while the highest number of sterile grains per panicle was obtained in Vilhena. The hybrid Ecco highlighted in relation to all other cultivars is in relation to tillering, panicle number per area and grain yield. The municipality of Cerejeiras is the most suitable for the cultivation of upland rice.
\end{abstract}

"Corresponding author. 


\section{Keywords}

\section{Oryza sativa L., Hybrid, Upland Rice, Genotype x Environment}

\section{Introduction}

By 2025 the world population will reach eight billion people, with $80 \%$ of those are in developing countries, and these countries will require a rational and efficient production to meet the demand of this population [1].

Among the cereals of great social and economic importance in the world, highlights the rice (Oryza sativa L.), which is an energy source for two-thirds of the world population, providing about $20 \%$ of energy and $15 \%$ of the protein that human needs [2]. In Brazil, rice is a major annual crop grown in all regions of the country [3].

The state of Rio Grande do Sul is responsible for $67 \%$ of Brazilian production of rice, which is grown in irrigated system [4]. However, in other states rice cultivation is mainly done in rainfed system. The cultivation of upland rice is characterized by the aerobic condition of root development of the plant. This farming system is found predominantly in Brazil and to a lesser extent in Africa [5].

Therefore, it is important to develop technologies to increase productivity in this system, since it benefits small, medium and large producers across the country [6]. The use of hybrid cultivars is a technology that can provide increased productivity of upland rice. However, in Brazil, there are few studies with hybrids of upland. The development and commercialization of hybrid rice in China began in 1976, with higher production by $20 \%$ over conventional varieties [7].

In rice cultivation, some factors must be considered for increasing productivity and economic [3] profitability. Among them, the choice of cultivars adapted to particular regions is very important.

In plant breeding programs, the process of selection and recommendation of genotypes is widely used to evaluate the performance of genotypes in different locations. The set of environmental factors that react with each other and interact with the plant, promoting changes in production and other agronomic affecting characteristics defines the genotype $\mathrm{x}$ environment interaction [8].

The genotype $\mathrm{x}$ environment interaction, in other words, when genotypes do not keep the same performance in the various environments in which they are grown, it is considered as a problem in breeding programs, because the ideal is that the genotypes exhibit high stability and productivity in different environments [9].

According to [4], in the 2012/2013 crop, rainfed farming was strongly affected by climate instability, undermining the productivity of crops, which underscores the importance of using cultivars with greater resistance to environmental change.

In this sense, the objective of this experiment was to evaluate the performance of six cultivars of upland rice in the municipalities of Cerejeiras and Vilhena, Rondônia State, Brazil.

\section{Material and Methods}

Two trials were conducted in the agricultural year 2010/2011, one at the Experimental Farm of the Faculty of the Amazon, in the municipality of Vilhena, Rondônia State, located at latitude $12^{\circ} 44^{\prime} 26^{\prime \prime} \mathrm{S}$ and at a longitude $60^{\circ} 08^{\prime} 45^{\prime \prime} \mathrm{W}$, altitude $612 \mathrm{~m}$ and the other, also in the experimental field of the Faculty Amazon in the municipality of Cerejeiras, State of Rondônia, located at altitude of $257.8 \mathrm{~m}, 13^{\circ} 11^{\prime} 19.6^{\prime \prime} \mathrm{S}$ latitude and $60^{\circ} 51^{\prime} 43.9^{\prime \prime} \mathrm{W}$ longitude. The precipitation in southern Rondônia is regular averaging $2023 \mathrm{~mm}$ in the period from October to June, when the crop cultivation is performed, with emphasis on the soybean, rice and corn. During this period temperatures are also favorable to agriculture, ranging from $22.1^{\circ} \mathrm{C}$ to $25.4^{\circ} \mathrm{C}$ [10].

Treatments consisted of seven genotypes, these being a hybrid (Ecco) and five conventional cultivars (BRS Monarca, BRS Primavera, AN Cambará, BRS Sertaneja and BRS MG Curinga) and two environments (Vilhena and Cerejeiras). The experimental design was a randomized block with four replications (or repeticions). Each experimental unit consisted of the area of $5 \times 2.0 \mathrm{~m}\left(10 \mathrm{~m}^{2}\right)$, this being sown eight lines of $5 \mathrm{~m}$ in length, spaced at $0,25 \mathrm{~m}$ apart. For harvesting discarded if two boundary lines and $0.5 \mathrm{~m}$ from each end of the plot.

The chemical characteristics of soils of the cities studied in the $0-20 \mathrm{~cm}$ layer, are presented in Table 1 . The soils were prepared in conventional cultivation system using disk harrow and leveling. Liming was performed 
Table 1. Chemical characterization of soils of the municipalities used in the experiment.

\begin{tabular}{|c|c|c|c|c|c|c|c|c|c|c|c|}
\hline \multicolumn{12}{|c|}{ Vilhena } \\
\hline $\mathrm{pH} \mathrm{CaCl}{ }_{2}$ & O.M.1 & $\mathrm{P}$ & K & $\mathrm{Ca}$ & $\mathrm{Mg}$ & $\mathrm{H}+\mathrm{Al}$ & $\mathrm{CEC}_{2}$ & $\mathrm{~B} \mathrm{~S}_{3}$ & \multicolumn{3}{|c|}{ Particle size $\left(\mathrm{g} \cdot \mathrm{dm}^{-3}\right)$} \\
\hline $0.01 \mathrm{~mol} \cdot \mathrm{L}^{-1}$ & $\mathrm{~g} \cdot \mathrm{dm}^{-3}$ & $\mathrm{mg} \cdot \mathrm{dm}^{-3}$ & \multicolumn{5}{|c|}{ mmolc $\cdot \mathrm{dm}^{-3}$} & $(\%)$ & Clay & Silt & Sand \\
\hline 5.5 & 15 & 4.8 & 0.9 & 15 & 9 & 3 & 55.5 & 46 & 180 & 20 & 800 \\
\hline \multicolumn{12}{|c|}{ Cerejeiras } \\
\hline $\mathrm{pH} \mathrm{CaCl}{ }_{2}$ & O.M. & $P$ & $\mathrm{~K}$ & $\mathrm{Ca}$ & $\mathrm{Mg}$ & $\mathrm{H}+\mathrm{Al}$ & CEC & B.S. & \multicolumn{3}{|c|}{ Particle size $\left(\mathrm{g} \cdot \mathrm{dm}^{-3}\right)$} \\
\hline $0.01 \mathrm{~mol} \cdot \mathrm{L}^{-1}$ & $\mathrm{~g} \cdot \mathrm{dm}^{-3}$ & $\mathrm{mg} \cdot \mathrm{dm}^{-3}$ & \multicolumn{5}{|c|}{$\mathrm{mmolc} \cdot \mathrm{dm}^{-3}$} & $(\%)$ & Clay & Silt & Sand \\
\hline 4.7 & 20 & 6.9 & 1.2 & 16 & 5 & 3.7 & 61.6 & 37.6 & 200 & 80 & 720 \\
\hline
\end{tabular}

1 Organic matter, 2 Cation exchange capacity e 3 Base saturation.

with calcined limestone ( $48 \%$ of $\mathrm{Ca}$ oxide, $16 \% \mathrm{Mg}$ oxide and relative power of the total neutralization of $124 \%$ ) at 40 days before planting, seeking to raise the base saturation to $50 \%$. Planting in Vilhena was held on December 6th and Cerejeiras on December 11, 2010. The seeding rate used was $80 \mathrm{~kg} \cdot \mathrm{ha}^{-1}$ for the five conventional cultivars and $40 \mathrm{~kg} \cdot \mathrm{ha}^{-1}$ for the hybrid.

The fertilization was done with $90-80-90 \mathrm{~kg} \cdot \mathrm{ha}^{-1}$ of nitrogen, phosphorus and potassium, respectively. Phosphorus was applied all at planting, along with $30 \%$ potassium and $30 \%$ nitrogen. In topdressing (20 days after emergence) was applied to $60 \%$ of nitrogen and potassium in the booting and the remaining $10 \%$. At planting was used as a source of phosphorus, superphosphate $(19 \% \mathrm{P})$, nitrogen, urea $(45 \% \mathrm{~N})$ and potassium, potassium $(65 \% \mathrm{~K})$. In topdressing nitrogen was supplied with ammonium sulfate $(21 \% \mathrm{~N})$ potassium with potassium chloride $(65 \% \mathrm{~K})$.

The weed control was done at 25 days after emergence herbicide with cyhalofop-butyl $\left(1.5 \mathrm{~L} \cdot \mathrm{ha}^{-1}\right)$ and Metsulfurom methyl ether $\left(3 \mathrm{~g} \cdot \mathrm{ha}^{-1}\right)$. The disease control was done with fungicide tricyclazole $\left(300 \mathrm{~g} \cdot \mathrm{ha}^{-1}\right)+$ tebuconazole $\left(750 \mathrm{~mL} \cdot \mathrm{ha}^{-1}\right)-50,70$ and 85 days after emergence, and insect control with application based insecticide permethrin $\left(150 \mathrm{~mL} \cdot \mathrm{ha}^{-1}\right)$ at 15 days after emergence.

The characteristics evaluated were: tillering-performed at 35 days after emergence (maximum tillering), measured on the line in a linear meter, number of panicles per area-both played was a square with an area of $0.25 \mathrm{~m}^{2}$ randomly in the center of each experimental unit, number of full grains per panicle and sterile, dry mass of grains per panicle - for this ten panicles were collected randomly from each experimental unit, the 1000 seeds - the counted sample taken from each experimental unit; yield $\left(\mathrm{kg} \cdot \mathrm{ha}^{-1}\right)$, and the mass of grain was adjusted to $13 \%$ moisture, and yield of whole grains - obtained through dairy equipment (tester rice model PAZ1DT).

After obtaining the data, analyzes of variance for each location and then a joint analysis of variance were performed environments. Means were compared by "Tukey $(\mathrm{P}<0.05)$ " [11] test.

\section{Results and Discussion}

The combined analysis of variance showed no significant cultivar $\mathrm{x}$ environment interaction in all traits (Table 2) effect, demonstrating that these factors act independently on these characteristics. Therefore, it will be discussed below that the isolated effect of environmental factors and cultivars on the performance of the culture of upland rice (Table 3 and Table 4). So we can infer the behavior of the cultivars did not vary significantly from one location to another. This fact is very important, considering that it is preferable cultivars producing high yield and stability in different environments, providing greater safety when producing the choice of the plant to be planted.

With respect to tillering and panicle number per area, Ecco hybrid was superior to all other cultivars (Table 2). As regards the environment, the average tillering and panicle number was higher in the municipality of Cerejeiras (Table 3).

According to [12] of hybrid rice plants has shown high phenotypic plasticity which results in increased tillering capacity than the conventional cultivars. The selection of materials with high capacity of the tillering becomes important because this is one of the main factors that directly influence yield, considering that the higher tillering, the greater the number of panicles per plant [13]. Still Second [14], tillering genotypes have advantage by adapting to various spacings and seeding rates, and also compensate for uneven sowing.

In this sense, it is noteworthy that the seeding density of the hybrid cultivar (Ecco) in this experiment was only $50 \%$ of conventional cultivars, which further demonstrates its high tillering capacity. 
Table 2. Summary of combined analysis of variance tillering (TI), number of panicles per area (PAN), number of whole grains (WG), number of sterile grains per panicle (SG), dry weight of grains per panicle (DWG), dry weight of 1000 seeds $(1000 \mathrm{~S})$, grain yield $\left(\mathrm{kg} \cdot \mathrm{ha}^{-1}\right)$ (YIELD) and whole grain yield (WGY), expressed in percentage.

\begin{tabular}{|c|c|c|c|c|c|c|c|c|c|}
\hline \multirow{2}{*}{ Causes of variation } & \multirow{2}{*}{ GL } & \multicolumn{7}{|c|}{ Mean square } & \multirow[b]{2}{*}{ WGY } \\
\hline & & TI & PAN & WG & SG & DWG & $1000 \mathrm{~S}$ & YIELD & \\
\hline Environment (E) & 1 & $4200^{*}$ & $12545,3^{*}$ & $162,9^{\text {ns }}$ & $1006,5^{* *}$ & $0,6^{\mathrm{ns}}$ & $15,3^{\text {ns }}$ & $2782484,3^{*}$ & $918,7^{* *}$ \\
\hline Cultivar (C) & 5 & $12810,3^{* *}$ & $14846,1^{* *}$ & $706,8^{\text {ns }}$ & $38,2^{\text {ns }}$ & $0,5^{\mathrm{ns}}$ & $6,9^{\text {ns }}$ & $3444081,8^{*}$ & $46,6^{\mathrm{ns}}$ \\
\hline $\mathrm{E} \times \mathrm{C}$ & 5 & $523,8^{\text {ns }}$ & $1248,5^{\mathrm{ns}}$ & $170,5^{\mathrm{ns}}$ & $23,3^{\text {ns }}$ & $0,2^{\mathrm{ns}}$ & $17,9^{\text {ns }}$ & $331111,6^{\mathrm{ns}}$ & $23,6^{\text {ns }}$ \\
\hline Block. d. E & 6 & $916,9^{\text {ns }}$ & $718^{\text {ns }}$ & $135^{\mathrm{ns}}$ & $8,7^{\mathrm{ns}}$ & $0,2^{\text {ns }}$ & $9,7^{\text {ns }}$ & $213661,8^{\mathrm{ns}}$ & $4,7^{\text {ns }}$ \\
\hline Resídue & 30 & 499 & 916,1 & 226,7 & 27,8 & 0,2 & 8,4 & 376864,4 & 19,2 \\
\hline
\end{tabular}

Significant at $(\mathrm{p}<0.05),{ }^{* *}$ Significant at $(\mathrm{p}<0.01),{ }^{\text {ns }}$ not significant.

Table 3. Average characteristics of tillering (TI), number of panicles per area (PAN), number of whole grains (WG), number of sterile grains per panicle (SG), dry weight of grains per panicle (DWG), dry weight 1000 grains (1000 S), grain yield $\left(\mathrm{kg} \cdot \mathrm{ha}^{-1}\right)(\mathrm{YIELD})$ and whole grain yield (WGY), expressed as a percentage of the municipalities Vilhena and Cerejeiras, Rondônia.

\begin{tabular}{ccccccccc}
\hline Environment & TI & PAN & WG & SG & DWG & $1000 \mathrm{~S}$ & YIELD & WGY \\
\hline Cerejeiras & $130,2 \mathrm{a}^{1}$ & $200,8 \mathrm{a}$ & 97,6 & $8,4 \mathrm{~b}$ & 2,47 & 25,2 & $3597,5 \mathrm{a}$ & $62,5 \mathrm{a}$ \\
Vilhena & $111,5 \mathrm{~b}$ & $168,5 \mathrm{~b}$ & 93,9 & $17,5 \mathrm{a}$ & 2,25 & 24,1 & $3115,9 \mathrm{~b}$ & $53,7 \mathrm{~b}$ \\
$\mathrm{MSD}^{2}(5 \%)$ & 16,9 & 26,2 & 9,7 & 3,6 & 0,32 & 3,1 & 427 & 3,6 \\
\hline
\end{tabular}

${ }^{1}$ Means followed by different lower case letters in the same column are significantly different (Tukey $\left.\mathrm{P}<0.05\right),{ }^{2}$ Minimum significant difference.

Table 4. Average of cultivar for tillering of tillering (TI), number of panicles per area (PAN), number of whole grains (WG), number of sterile grains per panicle (SG), dry weight of grains per panicle (DWG), dry weight 1000 grains (1000 $\mathrm{S})$, grain yield $\left(\mathrm{kg} \cdot \mathrm{ha}^{-1}\right)$ (YIELD) and whole grain yield (WGY), expressed in percentage.

\begin{tabular}{ccccccccc}
\hline Cultivar & TI & PAN & WG & SG & DWG & $1000 \mathrm{~S}$ & YIELD & WGY \\
\hline Ecco & $197,4 \mathrm{a}^{1}$ & $270 \mathrm{a}$ & 83,9 & 11,9 & 2,11 & 25,1 & $4652,2 \mathrm{a}$ & 58,7 \\
BRS Monarca & $128,2 \mathrm{~b}$ & $172 \mathrm{~b}$ & 96,4 & 15,6 & 2,46 & 25,7 & $3284,8 \mathrm{~b}$ & 59,6 \\
BRS Primavera & $88 \mathrm{~b}$ & $166,5 \mathrm{~b}$ & 108,9 & 14,2 & 2,65 & 24 & $3271,1 \mathrm{~b}$ & 55,1 \\
AN Cambará & $113,1 \mathrm{~b}$ & $158,5 \mathrm{~b}$ & 88,1 & 11,8 & 2,01 & 23,1 & $3106,7 \mathrm{~b}$ & 55,2 \\
BRS Sertaneja & $95,5 \mathrm{~b}$ & $156 \mathrm{~b}$ & 103,9 & 14,5 & 2,61 & 25,2 & $2962,2 \mathrm{~b}$ & 58,6 \\
BRS MG Curinga & $103,1 \mathrm{~b}$ & $185 \mathrm{~b}$ & 93,6 & 9,7 & 2,34 & 24,9 & $2863,1 \mathrm{~b}$ & 61,1 \\
MSD $^{2}(5 \%)$ & 48,8 & 75,4 & 27,8 & 10,3 & 0,93 & 9 & 1227,3 & 10,4 \\
\hline
\end{tabular}

${ }^{1}$ Means followed by different lower case letters in the same column are significantly different (Tukey $\mathrm{P}<0.05$ ), ${ }^{2}$ Minimum significant difference.

The cultivars were similar in relation to the number of whole grains per panicle, grain number per panicle sterile, mass of grains per panicle and weight of 1000 grains. [13] also found no significant differences between different genotypes of upland rice as the number of whole grains per panicle. It is also possible to observe that there was no interference from the environment these characteristics except the number of sterile grains per panicle, with the highest percentage of sterile grains observed in the municipality of Vilhena.

It is also observed that the highest yield was observed in the municipality of Cerejeiras. One factor that may have provided better tillering, fewer sterile spikelets per panicle and consequently higher productivity in the municipality of Cerejeiras is the highest content of organic matter in the soil profiles of this council, and this also showed higher cation exchange capacity (CEC), which is probably due to the greater amount of organic matter in the soil. Soils with higher organic matter and greater than $60 \mathrm{mmol} \cdot \mathrm{dm}^{-3} \mathrm{CTC}$ are more efficient at retaining water and nutrients, thus experiencing less leaching of nitrogen and potassium [15], a fact that becomes relevant, considering that the potassium content in the soil of the two environments was low, according to [16].

All cultivars had higher yields than the average of Rondônia state that was $2722 \mathrm{~kg} \cdot \mathrm{ha}^{-1}$ in the same season [17], especially hybrid that reached $1930 \mathrm{~kg} \cdot \mathrm{ha}^{-1}$ more than the state average, and this was also the most produc- 
tive among the cultivars evaluated (Table 4), exceeding by $50 \%$ the average productivity achieved by the other cultivars, confirming [1] who reported that hybrid rice genotypes can increase rice productivity in more $25 \%$.

With this, we can say that among the characteristics evaluated tillering is what really influenced the productivity of upland rice. [18] reported better root development for hybrid Ecco relative BRS Primavera BRS Sertaneja and AN Cambará, which provides that the greater absorption of water and nutrients thereby resulting in obtaining from higher yields.

There were no significant differences among cultivars for yield of whole grains. Brazilian law provides effective yield $40 \%-68 \%$ for whole grains [19] therefore the percentage yield observed for the materials tested exceeded the minimum percentage required. The best yield of whole grains was observed in the city of Cerejeiras. Thus, we can classify this municipality as most suitable for the cultivation of upland rice, because in addition to the higher productivity achieved by cultivars also had the highest yield of whole grains in this municipality, which in practice means greater profitability for the producer rural.

\section{Conclusion}

There was no cultivar $\mathrm{x}$ environment interaction for all traits. Ecco the hybrid is the most productive among all tested cultivars. The municipality of Cerejeiras is the most suitable for the cultivation of upland rice.

\section{Acknowledgements}

The Brazilian Agricultural Research Corporation (EMBRAPA), the Rack-Industry and Trade of Rice Ltda. $\left(\right.$ RICAL $\left.^{\circledR}\right)$ and the RiceTec ${ }^{\circledR}$.

\section{References}

[1] Kennedy, A.C. and Smith, K.L. (1995) Soil Microbial Diversity and the Sustainability of Agricultural Soils. Plant and Soil, 170, 75-86. http://dx.doi.org/10.1007/BF02183056

[2] Barberena, D.S., Medeiros, R.D. and Barbosa, G.F. (2011) Growth and Productivity of Irrigated Rice in Response to Different Doses of Phosphorus and Potassium in Lowland Soil of First Year in the State of Roraima. Science and Agrotechnology, 35, 462-470. http://dx.doi.org/10.1590/S1413-70542011000300004

[3] Barreto, J.H.B., Soares, I., Pereira, J.A., Bezerra, A.M.E. and Deus, J.A.L. (2012) Yield Performance of Upland Rice Cultivars at Different Rates and Times of Nitrogen Application. Brazilian Journal of Soil Science, 36, 475-483. http://dx.doi.org/10.1590/S0100-06832012000200017

[4] CONAB - National Supply Company (2013) Brasilian Crop Assessment: Grains, Twelfth Assessment, September. http://www.conab.gov.br/OlalaCMS/uploads/arquivos/13 $10 \quad 16 \quad 14 \quad 32 \quad 01$ boletim ingles - setembro 2013.pdf

[5] Guimarães, C.M. (2006) Rice Cultivation in Brazil. 2nd Edition. Embrapa Arroz e Feijão, Santo Antônio de Goiás.

[6] Gitti, D.C., Arf, O., Portugal, J.R., Corsini, D.C.D.C., Rodrigues, R.A.F. and Kaneko, H. (2013) Cover Crops, Nitrogen Rates and Seeds Inoculation with Azospirillum Brasilense in Upland Rice under No-Tillage. Bragantia, 71, 509517. http://dx.doi.org/10.1590/S0006-87052013005000002

[7] Menezes, V.G. and Ramirez, H.B. (2003) Management Strategies Aimed at Increasing the Competitiveness and Sustainability in Irrigated Rice Production. In: National Congress of Rice Production Chain/VII Meeting of Rice Crop Research, EMBRAPA, Santo Antônio de Goiás, 2003, 280 p.

[8] Pires, L.P.M., Peluzio, J.M., Cancellier, L.L., Ribeiro, G.R., Colombo, G.A. and AfFerri, R.S. (2012) Performance of Soybean Genotypes in Central-South Region on Tocantins State, Crop Season 2009/2010. Bioscience Journal, 28, 214223.

[9] Regitano Neto, A., Ramos Júnior, E.U., Gallo, P.B., Freitas, J.G. and Azzini, L.E. (2013) Behavior of Upland Rice Genotypes in the State of São Paulo, Brazil. Agronomic Science Magazine, 44, 512-519. http://dx.doi.org/10.1590/S1806-66902013000300013

[10] Furlan, D.N., Nunes, D.D., da Silva, J.M., Lobato, L.C.H., Lima, T.R., de Assunção, A.G. and Pinto, G.C. (2010) Climate and Soybean Yields in the Municipalities of Cherry and Vilhena Located in the Southern Cone of Rondônia. http://www.cbmet.com/cbm-files/14-9e178324fe343881898c4f98651b1a7d.pdf

[11] Pimentel-Gomes, F. (2009) Statistics Course Experimental. 15th Edition. FEALQ, Piracicaba.

[12] Yuan, L., Yang, Z. and Yang, J. (1994) Hybrid Rice in China. In: Virmani, S.S., Ed., Hybrid Rice Technology: New Developments and Future Prospects, International Rice Research Institute, Los Baños, Philippines, 143-147.

[13] Silva, V.A.C., Silva, E.F. and Tabosa, J.N. (2010) Performance of Upland Rice Genotypes in "Zona da Mata” of Per- 
nambuco State. Brazilian Journal of Agricultural and Environmental Engineering, 14, 1030-1037. http://dx.doi.org/10.1590/S1415-43662010001000002

[14] YOSHIDA, S. (1981) Fundamentals of Rice Crop Science. IRRI, Los Baños.

[15] Lopes, A.S. and Guimarães Guilherme, L.R. (2004) Interpretation of Analysis of Soil. Concepts and Applications, National Association for Diffusion of Fertilizers (ANDA). http://www.anda.org.br/multimidia/boletim 02.pdf

[16] Raij, B.V., Cantarella, H., Quaggio, J.A. and Furlani, A.M.C. (1997) Lime and Fertilizer Recommendations for the State of São Paulo. 2nd Edition, Instituto Agronômico, Campinas.

[17] CONAB - National Supply Company (2011) Brasilian Crop Assessment: Grains, Twelfth Assessment, June. http://www.conab.gov.br/OlalaCMS/uploads/arquivos/11 $07 \quad \begin{array}{lllllll}15 & 11 & 03 & 18 & \text { boletim julho - 2011..pdf }\end{array}$

[18] Soares, E.R., Baseggio, E.A., Londrero, L.S., Correa, S.C.S., Rossini, V.P., Zo-linger, I.T., Klahold, C.A. and Galon, L. (2010) Production and Productivity Components of Hybrid Rice Dry Compared to Conventional Three Cultivars. Agricultural Act, 59, 435-441.

[19] Vieira, N.R.A. and Carvalho, J.L.V. (1999 Technological Quality. In: Veira, N.R.A., Santos, A.B. and Santana, E.P., Eds., Rice Cultivation in Brazil, Embrapa Arroz e Feijão, Santo Antonio de Goiás, 582-598. 